\title{
SECRETIN PREVENTS HYPOREACTIVE AND MORPHOLOGICAL RESPONSES OF RAT PANCREATIC ACINAR CELLS TO STIMULATION WITH SUPRAOPTIMAL CONCENTRATION OF CHOLECYSTOKININ-OCTAPEPTIDE
}

\author{
Tomio Kanno', Takehisa Matsumoto', Michio Mori², Masahito Oyamada ${ }^{2}$ \\ and Timo J. Nevalainen ${ }^{3}$ \\ ${ }^{1}$ Department of Physiology, Faculty of Veterinary Medicine, Hokkaido University, Sapporo 060, \\ ${ }^{2}$ Department of Pathology, Sapporo Medical College, Sapporo 060, Japan, and ${ }^{3}$ Department of \\ Pathology, University of Turku, Turku 52, Finland
}

\begin{abstract}
Secretagogues at concentrations greater than those required for maximum secretory responses (as measured in pancreatic protein output and juice flow) induce submaximal responses. In the isolated perfused rat pancreas, a high concentration of cholecystokininoctapeptide ( 1 or $100 \mathrm{nM}$ CCK-8) produced secretory responses significantly smaller than maximal responses. This hyporeactive response to supraoptimal stimulation coincided with a profound alteration in acinar cell morphology as follows: 1) disappearance of microvilli from the luminal acinar cell surface, 2) appearance of cytoplasmic 'lakes' of zymogen material bounded by a membrane and located among normal looking mitochondria and cisternae of granular endoplasmic reticulum, and 3) destruction of cytoplasmic microfilaments detected immunohistochemically by an anti-actin antibody. In contrast to these alterations, stimulation with $1 \mathrm{nM} \mathrm{CCK}-8$ in combination with $100 \mathrm{pM}$ secretin: 1) preserved the acinar cell ultrastructure and microfilaments so that they resembled those in the control pancreas (without stimulation) and pancreas stimulated with lower doses of CCK-8; and 2) regained the maximal secretory responses equivalent to those with the optimal CCK- 8 concentration of $100 \mathrm{pM}$. It is concluded, therefore, that: 1) secretin prevents the hyporeactive and morphological alteration of pancreatic acinar cell induced by supraoptimal stimulation with CCK-8; and 2) the alterations may be mediated by microfilaments containing immunoreactive actin. These observations provide an experimental basis for the administration of secretin to prevent the development of pancreatitis induced by a supraoptimal plasma CCK level.
\end{abstract}

Functionally, the exocrine pancreas consists of acinar tissue and ductal tissue. Stimulus-secretion coupling in the acinar cells is initiated by the activation of a receptor for the peptide hormone, cholecystokinin-pancreozymin (CCK), as well as by the activation of a muscarinic cholinergic receptor $(4,36)$. Pancreatic juice secretion by the ductal cells is regulated by another peptide hormone, secretin, and a neurotransmitter of the vagus nerve, vasoactive intestinal polypeptide (VIP) (8). Studies in recent years have developed the view that, on the acinar cell, not only CCK and cholinergic receptors but also secretin and VIP receptors are present (10). Interactions among the intracellular processes followed by the activation of these receptors have also been studied.

Stimulation of the acinar tissue with various 
doses of CCK and acetylcholine (ACh) is characterized by a biphasic dose-response relation both in vivo and in vitro $(6,9,11,13,14,20,25,30-33)$. With increasing concentration of these secretagogues, secretory responses increased until maximal responses which are elicited at optimal concentrations. At concentrations of secretagogues higher than the optimal concentration, the enzyme output declines. This hyporeactive response to high secretagogue concentrations is time-dependent: the rate of enzyme secretion is greater during the initial minutes of incubation than it is at later times in the isolated acini $(1,35)$; and, in the isolated perfused pancreas, continuous stimulation with $1.4 \mathrm{nM}(20 \mathrm{mU} / \mathrm{ml})$ CCK induced transient rises in secretory responses followed by a rapid decline (14). Stimulation of the isolated perfused rat pancreas with $\mathrm{CCK}$ or $\mathrm{ACh}$ at various concentrations is characterized by a biphasic dose-response relation for pancreatic protein output, which coincided with a similar biphasic relation for juice flow $(11,14,16)$.

The isolated perfused pancreas has the advantage that it can be fixed quickly for morphological studies at any stage of stimulus-secretion coupling by replacing the perfusion solution with a fixative. Taking advantage of this preparation, we found that the hyporeactive responses to supraoptimal CCK-8 concentrations was associated with the following profound morphological changes in the acinar cells: formation of spherical protrusions and large vacuoles, disappearance of microvilli, and destruction of cytoplasmic microfilaments, which contained immunoreactive actin. The most prominent result in the present study was that secretin prevented the time-dependent hyporeactive responses (pancreatic protein output and juice flow) and the concomitant morphological changes in acinar cell ultrastructure and microfilaments which were induced by the supraoptimal concentration of CCK-8.

\section{MATERIALS AND METHODS}

\section{Isolation and Perfusion of the Pancreas}

Sprague Dawley strain rats (about $200 \mathrm{~g}$ ) were fasted but allowed water for $24 \mathrm{~h}$ before each experiment. The isolated and perfused pancreas was prepared as reported previously (17). Briefly, under ether anesthesia, the vascular system was cannulated and perfused through the superior mesenteric and coeliac arteries, with the portal vein as outlet. The rate of vascular flow was kept constant at $2 \mathrm{ml} / \mathrm{min}$ by a roller pump. The hepatic end of the duct was ligated and the pan- creatic juice was collected from the duodenal end by means of a stainless steel cannula. The blood supplying the stomach, liver, and spleen was stopped by tying the arteries. The mesentery with its embedded whole pancreas and attached duodenum was isolated, and then placed in a Lucite chamber containing $20 \mathrm{ml}$ of a HEPESbuffered Ringer solution, maintained at $37^{\circ} \mathrm{C}$.

\section{Solution and Drugs}

The composition of the standard HEPES-buffered Ringer solution used for perfusing and bathing the preparation was as follows (mM): $\mathrm{NaCl}, 145 ; \mathrm{KCl}, 5.6 ; \mathrm{CaCl}_{2}, 2.5 ; \mathrm{MgCl}_{2}, 1$; HEPES ( $N$-2-Hydroxyethyl piperazine- $N$-2ethane sulfonic acid; Sigma), 10; glucose, 5. Dextran T-70 (Pharmacia, Uppsala) was added to the perfusing solution (16). COOH-terminal residue of CCK (CCK-8) was added to the perfusing solution. Synthetic CCK-8 and synthetic VIP were gifts of Professor Yanaihara (Shizuoka College of Pharmacy, Shizuoka, Japan), and pure natural secretin was a gift of Professor Mutt (Karolinska Institute, Stockholm, Sweden).

\section{Estimation of Digestive Enzyme}

The collected juice sample was then diluted with $160 \mathrm{mM} \mathrm{NaCl}$ solution containing phosphate buffer ( $\mathrm{pH}$ 7.1). The total protein in the pancreatic juice was assayed by the method of Lowry et al. (21) with bovine serum albumin as a standard.

\section{Statistics}

Results are expressed as the mean \pm SE of several experiments, and are analyzed by Student's $t$ test.

\section{Electron Microscopy}

After a $30 \mathrm{~min}$ period of stimulation with CCK, or with CCK and secretin, the pancreas was prepared for electron microscopy as follows: perfused for 10 min with a fixative, which consisted of $1 \%$ glutaraldehyde, $4 \%$ formaldehyde and $0.1 \mathrm{M}$ cacodylate buffer at $\mathrm{pH} 7.4$; minced; placed in the same fixative for an additional 24$48 \mathrm{~h}$; postfixed in $1 \%$ osmium tetroxide in $0.1 \mathrm{M}$ cacodylate buffer for $1 \mathrm{~h}$, and embedded in Epon. Semithin $(1 \mu \mathrm{m})$ sections were stained with toluidine blue and thin $(80 \mathrm{~nm})$ sections with uranyl acetate and lead citrate. Glutaraldehyde and formaldehyde-fixed tissues were also 
reacted with ruthenium red, which added to the osmium tetroxide-fixative to demonstrate acid mucopolysaccharides of the cell surface (22). The Epon sections of these tissues were studied without further staining.

\section{Immunohistochemical Staining of Actin}

Tissues for the immunohistochemical demonstration of actin (microfilaments) were perfused at the end of the stimulation period successively with the following fluids: 1) $0.2 \%$ Triton $\times 100$ in a cytoskeleton-stabilizing buffer at $\mathrm{pH} 6.9$ (10 $\mathrm{mM}$ piperazine- $N, N^{\prime}$-bis 2 ethane sulfonic acid (PIPES), $1 \mathrm{mM} \mathrm{MgCl} 2,2 \mathrm{mM}$ EGTA, 5\% polyethylene glycol $6000,5 \%$ glycerol) for 10 min; 2) 4\% paraformaldehyde and $0.5 \%$ glutaraldehyde in $80 \%$ phosphate-buffered saline (PBS) for $10 \mathrm{~min}$; and 3) $0.05 \% \mathrm{NaBH}_{4}$ in PBS for $8 \mathrm{~min}$. After rinsing with cold PBS for 2 days, the tissues were dehydrated and embedded in paraffin. Five-micron sections were incubated with the anti-chicken backmuscle actin antibody (1:160-320), after the inactivation of endogenous peroxidase. A subsequent application of goat anti-rabbit-IgG serum was followed by incubation with a rabbit anti-peroxidase-peroxidase complex (PAP). The diaminobenzidine reaction was used to localize the bound peroxidase; which yielded a brown reaction product. The sections were finally counterstained with $1 \%$ methyl green.

\section{RESULTS}

\section{Secretory Responses Induced by CCK-8 in Different Concentrations}

The isolated rat pancreas was first perfused with standard solution for $30 \mathrm{~min}$ to reach steady levels after which the pancreas was continuously stimulated with CCK-8 for $40 \mathrm{~min}$, and finally, the CCK-8 solution was replaced with the standard solution. Continuous stimulation with CCK-8 at a physiological concentration (10 pM; $5,16)$ induced steady levels of secretory responses as measured in the pancreatic protein output and juice flow (Fig. 1a). The total protein output in the $40 \mathrm{~min}$ of continuous stimulation in the standard solution was $4.73 \pm 0.47 \mathrm{mg}$ / 40 min. Continuous stimulation with CCK-8 at optimal concentration $(100 \mathrm{pM})$ induced maximal secretory responses which consisted of two phases, an initial rise and a slow decline (Fig. 1b). The total protein output in the $40 \mathrm{~min}$ of con-
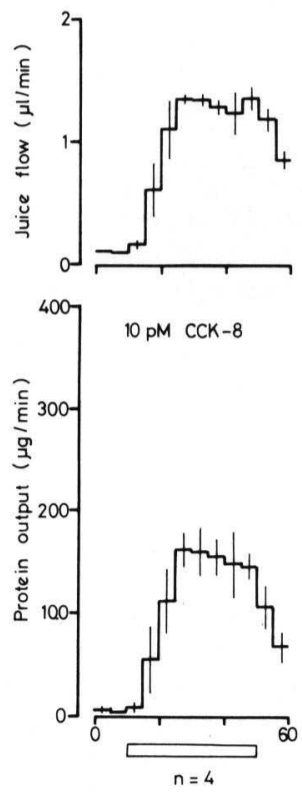

b

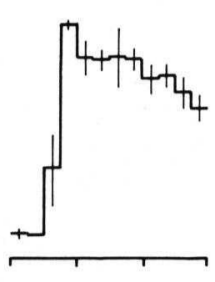

100 pM CCK-8

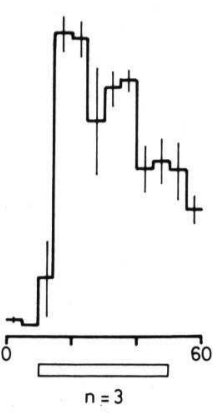

c

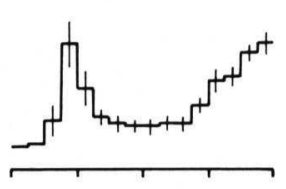

$1 \mathrm{nM} \mathrm{CCK}-8$

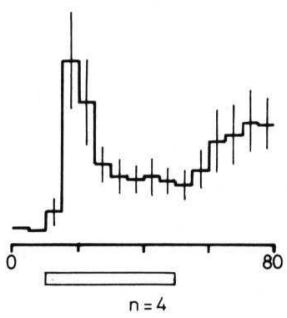

d
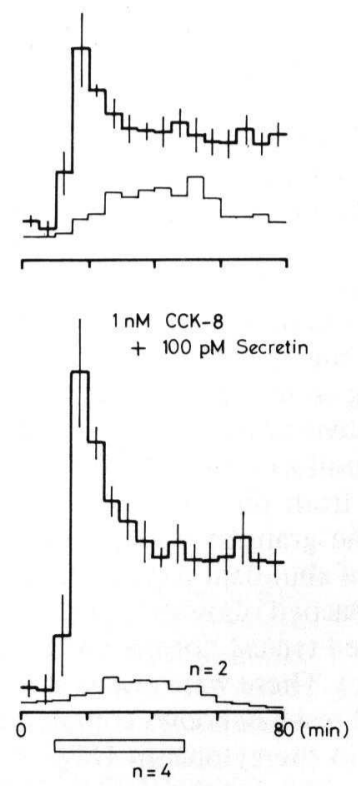

Fig. 1 Time course of changes in pancreatic juice flow and protein output during continuous perfusion of the isolated rat pancreas with 10 pM CCK-8, 100 pM CCK- 8,1 nM CCK- 8 and 1 nM CCK- $8+100$ pM secretin. The thin line in the figures on the right represents the response to $100 \mathrm{pM}$ secretin alone. Each value represents the mean $( \pm \mathrm{SE})$ of several experiments as indicated (n). The open horizontal bar indicates the period of CCK-8 perfusion; $n$ is the number of experiments. 
tinuous stimulation was $8.44 \pm 0.55 \mathrm{mg} / 40 \mathrm{~min}$. Continuous stimulation with CCK-8 at a supraoptimal concentration $(1 \mathrm{nM})$ induced secretory responses which consisted of two phases, an initial small rise and a rapid decline (Fig. 1c). The total protein output in the $40 \mathrm{~min}$ of continuous stimulation was $3.45 \pm 0.78 \mathrm{mg} /$ $40 \mathrm{~min}$. Combined continuous stimulation with CCK-8 (1 nM) and secretin (100 pM) induced secretory responses which were similar to those induced by stimulation with CCK-8 at the optimal concentration of $100 \mathrm{pM}$ (Fig. 1d). The total protein output in the $40 \mathrm{~min}$ of continuous stimulation was $7.69 \pm 0.60 \mathrm{mg} / 40 \mathrm{~min}$, which is significantly larger than that induced by stimulation with $1 \mathrm{nM} \mathrm{CCK}-8(P<0.01)$, and is not significantly different from that produced with $100 \mathrm{pM}$ CCK-8 $(P>0.05)$. These results show that $100 \mathrm{pM}$ secretin can prevent the hyporeactive responses to supraoptimal stimulation with $1 \mathrm{nM}$ CCK-8. The pattern of juice flow induced by stimulation with the secretagogues was almost identical to that of protein output, and the amount of juice flow induced by the combined stimulation with $1 \mathrm{nM} \mathrm{CCK}-8$ and $100 \mathrm{pM}$ secretin was significantly larger than that induced by 1 nM CCK-8 alone $(P<0.01)$.

\section{Ultrastructure of Acinar Cells}

In the isolated rat pancreas perfused without added secretagogues for $30 \mathrm{~min}$, the acinar cells showed well preserved ultrastructure (Fig. 2a) similar to that described earlier in rat pancreas in vivo (24). The acinar cells were cuboidal in shape and the extracellular space between adjacent acinar cells was narrow. There were numerous round, uniform, relatively dense zymogen granules in the apical cytoplasm (Fig. 2b), and condensing vacuoles in the supranuclear Golgi area. The acinar lumen was small and empty except short uniform microvilli protruding into the lumen from the apical acinar cell surface (Fig. $2 b)$. The granular endoplasmic reticulum consisted of abundant parallel stacks of membranes with attached ribosomes (Fig. 2c). Mitochondria displayed typical normal ultrastructural features (Fig. 2c). There were occasional lysosomes (Fig. 2a) and residual bodies containing membranous debris in the cytoplasm (Fig. 2c).

After 30 min stimulation with either $10 \mathrm{pM}$ (Fig. 3a) or 100 pM (Fig. 3b) CCK-8 the acinar cell ultrastructure was unchanged. The zymogen granules appeared homogeneous, round, and approximately $1 \mu \mathrm{m}$ in diameter and the acinar lumen and the apical microvilli were similar to those of the control glands. Ruthenium red stained well the outside of the basal plasma membrane of the acinar cells (Fig. 3c) but the staining was absent from the lateral and apical plasma membranes.

In the glands stimulated either with $1 \mathrm{nM}$ or 100 nM CCK-8 the acinar cell ultrastructure was profoundly altered. The acinar cells appear round in shape but were firmly attached to each other along the lateral plasma membranes (Fig. 4a). The acinar lumina were somewhat dilated and contained homogeneous, dense material, which resembled the contents of zymogen granules (Fig. 4, a, b and c). Another change in the ultrastructure of the lumen was the disappearance of microvilli from the apical acinar cell surface which resulted in a smooth contour of the acinar lumen (Figs. 4b and 5a). There were occasional foci of cytoplasmic degeneration (Fig. 4c) which resembled the residual bodies seen in the normal unstimulated glands (Fig. 2c). Especially in the gland stimulated with the highest doses of CCK$8(100 \mathrm{nM})$ there were large intracytoplasmic accumulations of zymogen-like material (Fig. 5, b, c and d). In the same cells the zymogen granules were often enlarged and deformed in shape (Fig. 5c). The cytoplasmic 'lakes' of zymogen material approached the acinar cell nucleus in size (Fig. 5, b and c), were bounded by a membrane, and located among normal-looking mitochondria and cisternae of the granular endoplasmic reticulum. The ruthenium red staining revealed slightly more complex basal plasma membrane corresponding to the rounding of the acinar cells (Fig. 5e). Ruthenium red stained the basal plasma membrane only where the lateral and apical plasma membranes remained unstained (Fig. 5f).

In the glands stimulated with $1 \mathrm{nM} \mathrm{CCK}-8$ in combination with $100 \mathrm{pM}$ secretin, the acinar cell ultrastructure was different from that of the glands stimulated with the high doses of CCK-8 only, but resembled that of the non-stimulated control glands and glands stimulated with the lower dose of CCK-8. Addition of secretin to CCK-8 thus prevented the deformation of zymogen granules and the accumulation of zymogen material in the acinar lumen and in the cytoplasmic 'lakes' (Fig. 6, a and b). The acinar lumina appeared normal, although larger than in the unstimulated control glands or glands stimulated with CCK-8 only. The microvilli on the apical acinar cell surface appeared normal and there was electron-lucid, finely granular secretory material in the acinar lumen (Fig. 6b). 

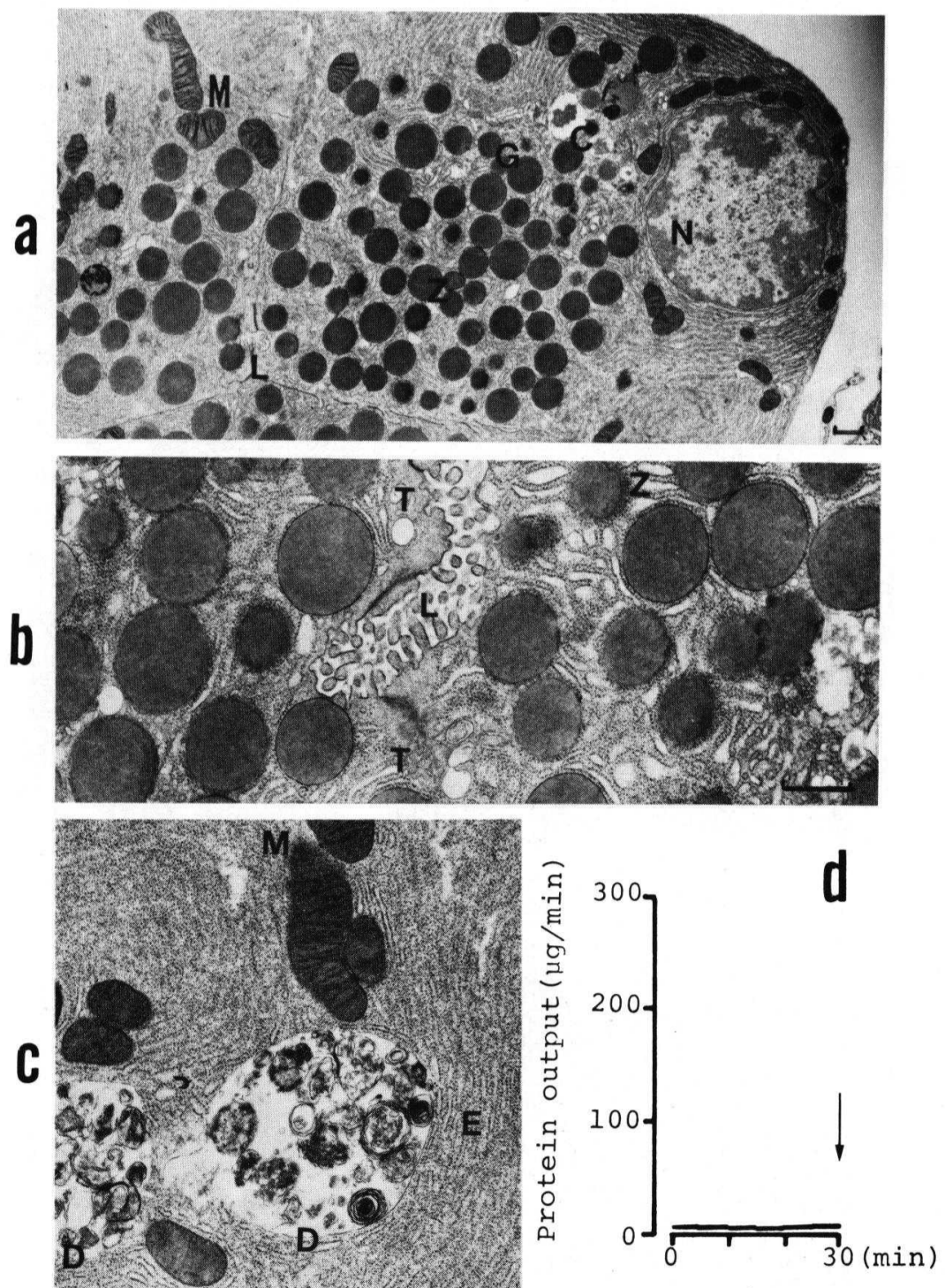

Fig. 2 Ultrastructure of pancreatic acinar cell without CCK-8. a: Three acinar cells around the inconspicious acinar lumen (L). There are abundant round zymogen granules (Z) in the apical cytoplasm. N, nucleus; M, mitochondria; G, Golgi apparatus; $\mathrm{C}$, condensing vacuoles. The horizontal bar represents $1 \mu \mathrm{m}$ calibration. b: The acinar lumen (L) is small and empty except for microvilli protruding into it. Z, zymogen granules; T, tight junctions at the lumen between adjacent acinar cells. Calibration as in a. c: Small areas of membrane-bounded focal cytoplasmic degeneration (D) among cisternae of the granular endoplasmic reticulum (E) and mitochondria (M). Calibration as in a. d: Time course of protein output in the preparation examined by electron microscopy. The arrow shows the beginning of perfusion fixation. 

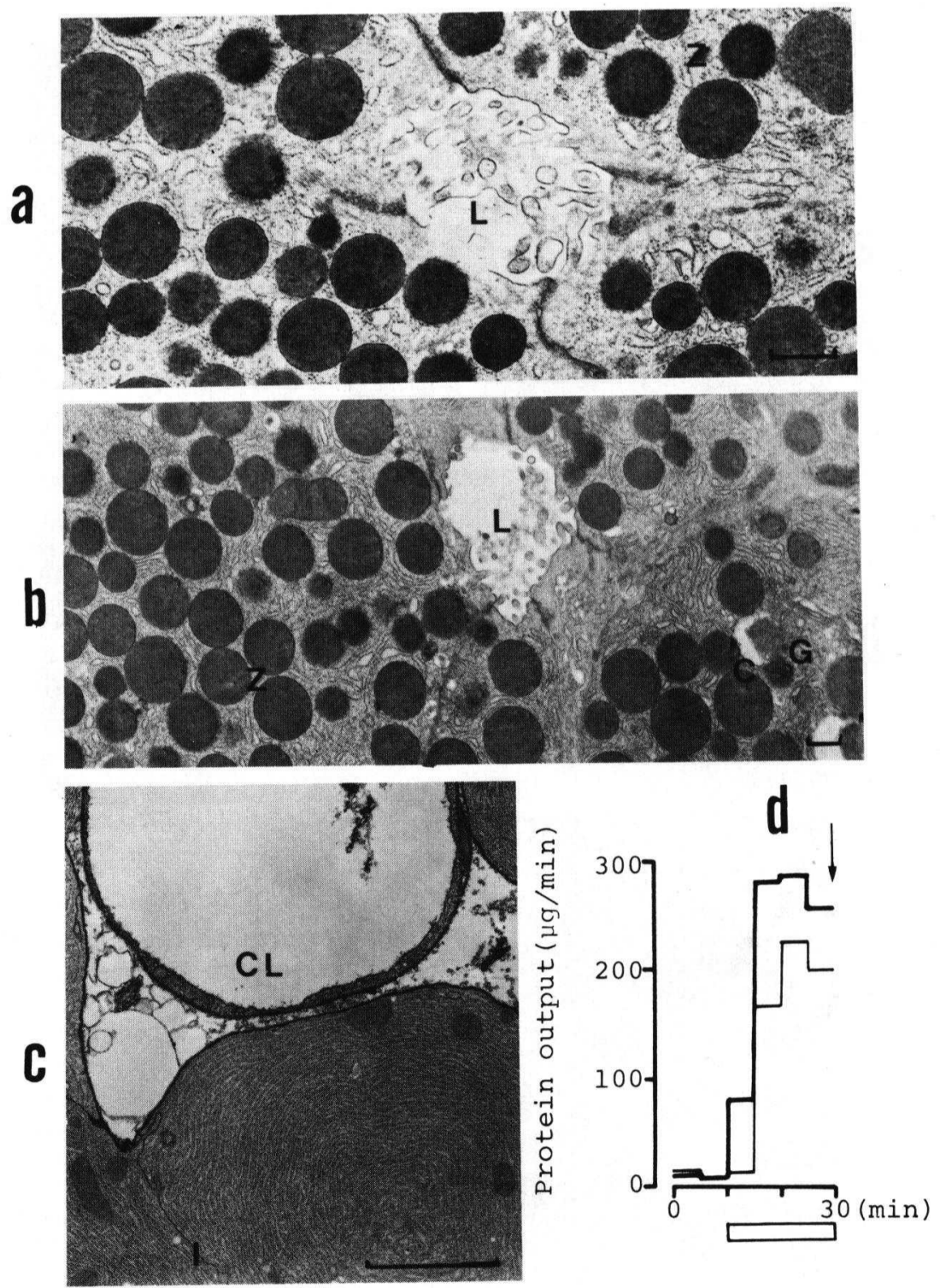

Fig. 3 Electron micrographs of pancreatic acinar cell after continuous stimulation with 10 pM. CCK-8. a: The acinar lumen (L), zymogen granules $(\mathrm{Z})$ and other organelles show normal ultrastructure. Note the microvilli protruding into the acinar lumen. The horizontal bar represents $1 \mu \mathrm{m}$ calibration. b: Electron micrograph after continuous stimulation with 100 pM CCK-8. Acinar lumen (L), zymogen granules, and other organelles show normal ultrastructure. Some dilatation of the Golgi cisternae $(\mathrm{G})$ and the condensing vacuoles (C) as well as the acinar lumen is evident. The acinar lumen is devoid of secretory material. Calibration as in a. c: Electron micrograph after continuous stimulation with $100 \mathrm{pM}$ CCK-8. Note distribution of ruthenium red-reactive material at the basal lamina of acinar cells. Note the absence of the staining in the intercellular space (I). CL, capillary lumen. Calibration as in a. d: Time course of protein output of the preparations examined by electron microscopy before and after continuous stimulation with $10 \mathrm{pM}$ (thin line) or $100 \mathrm{pM}$ CCK-8 (thick line). Other symbols as in Fig. 2 

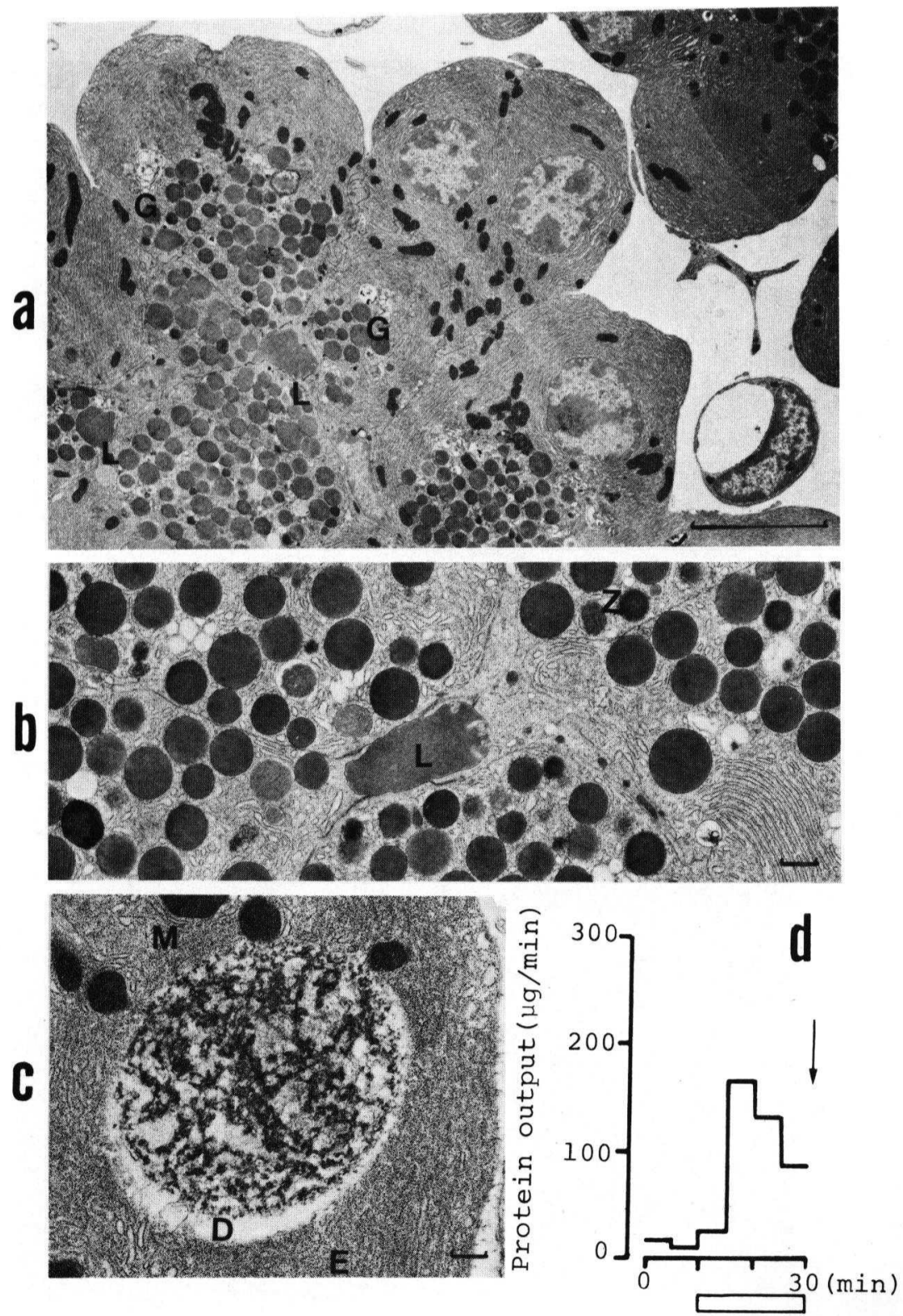

Fig. 4 Electron micrographs after continuous stimulation with 1 nM CCK-8. a: Acinar cells show a round form, dilatation of Golgi cisternae $(\mathrm{G})$, and enlarged acinar lumina (L). The horizontal bar represents $10 \mu$ m calibration. b: The acinar lumen (L) contains homogeneous secretory material and there are no microvilli on the luminal plasma membrane. The zymogen granules $(\mathrm{Z})$ and other organelles appear normal. The horizontal bar represents $1 \mu \mathrm{m}$ calibration. c: A small area of focal cytoplasmic degeneration (D) among cisternae of the granular endoplasmic reticulum (E) and mitochondria (M). Calibration as in b. d: Time course of protein output of the preparation examined by electron microscopy before and after continuous stimulation with $1 \mathrm{nM} \mathrm{CCK}-8$. Other symbols as in Fig. 2 

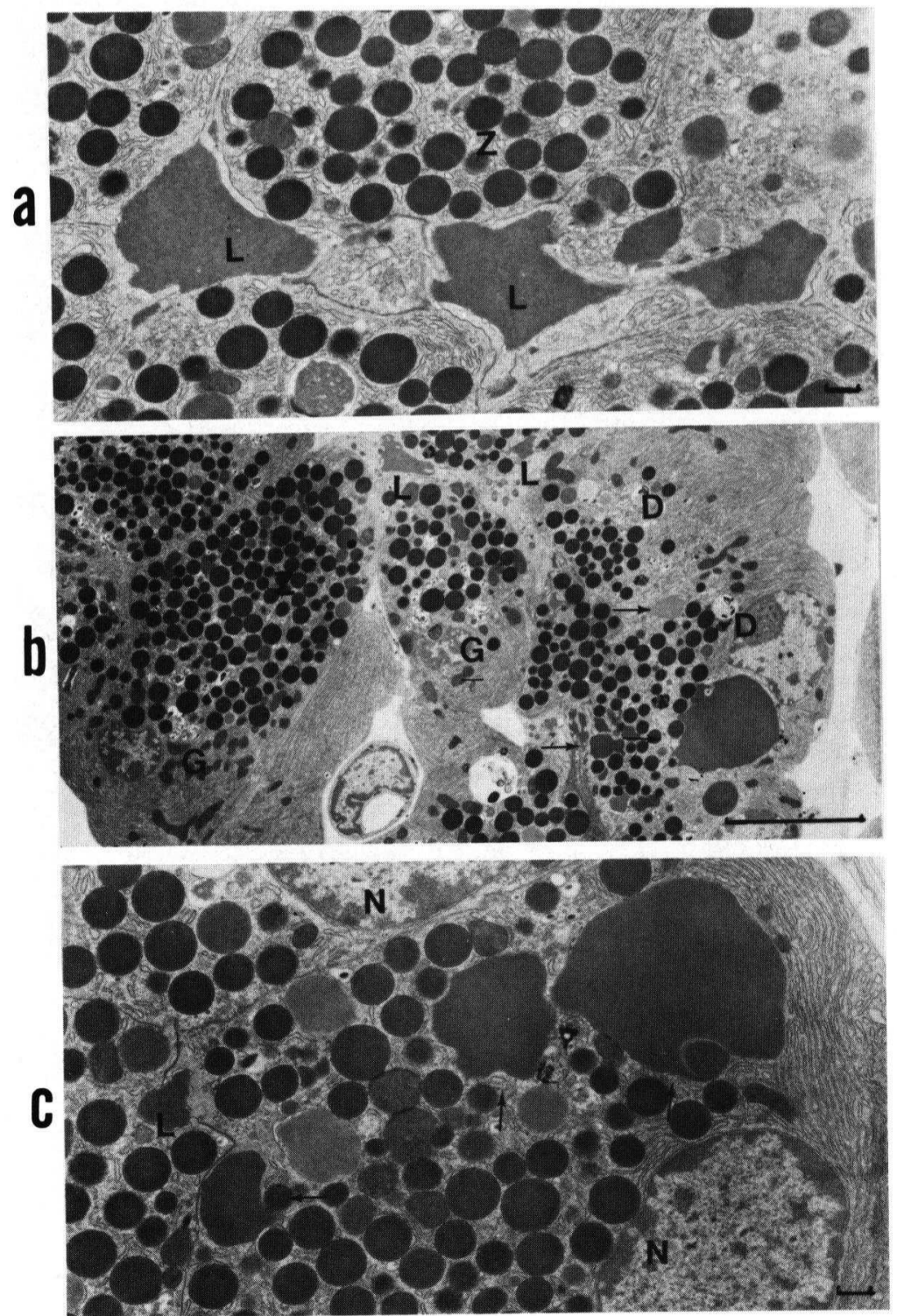

Fig. 5 Electron micrographs after continuous stimulation with $100 \mathrm{nM} \mathrm{CCK-8.} \mathrm{a:} \mathrm{Dilated}$ acinar lumina contain homogeneous material but no microvilli. Zymogen granules (Z) and other organelles appear normal. The horizontal bar represents $1 \mu \mathrm{m}$ calibration. b: Dilated acinar lumina (L) and intracytoplasmic accumulations of secretory material (arrows). Zymogen granules (Z) appear normal, whereas the Golgi cisternae (G) are dilated. There are numerous small areas of focal cytoplasmic degeneration (D) in the acinar cells. The horizontal bar represents $10 \mu \mathrm{m}$ calibration. c: There are numerous large accumulations of secretory material in the cytoplasm (arrows). L, acinar lumen; $\mathrm{N}$, nucleus. Calibration as in a. d: A large, membrane-bounded 'lake' of secretory material in the acinar 

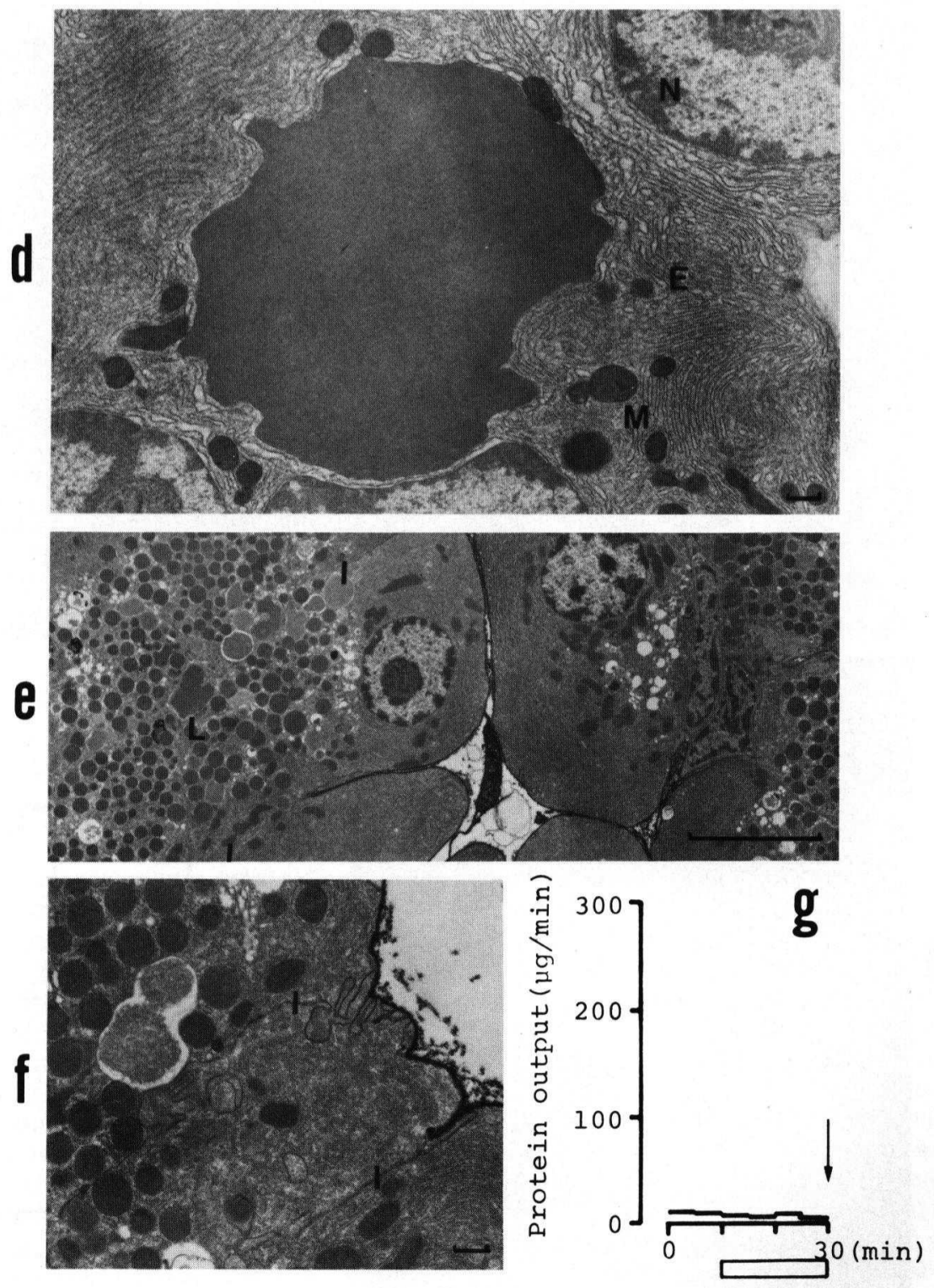

cell cytoplasm. E, granular endoplasmic reticulum; M, mitochondria; N, nucleus. Calibration as in a. e: Ruthenium red-reactive material in the basal lamina of acinar cells. Note the absence of the reaction product from the intercellular spaces (I) and the acinar lumen (L). Calibration as in b. $\mathrm{f}$ : Higher magnification of the ruthenium red-reaction product on the basal lamina of acinar cells. The reaction product is finely granular. It is absent from the intercellular space (I). Calibration as in a. g: Time course of protein output of the preparation examined by electron microscopy before and after continuous stimulation with $100 \mathrm{nM}$ CCK-8. Other symbols as in Fig. 2 

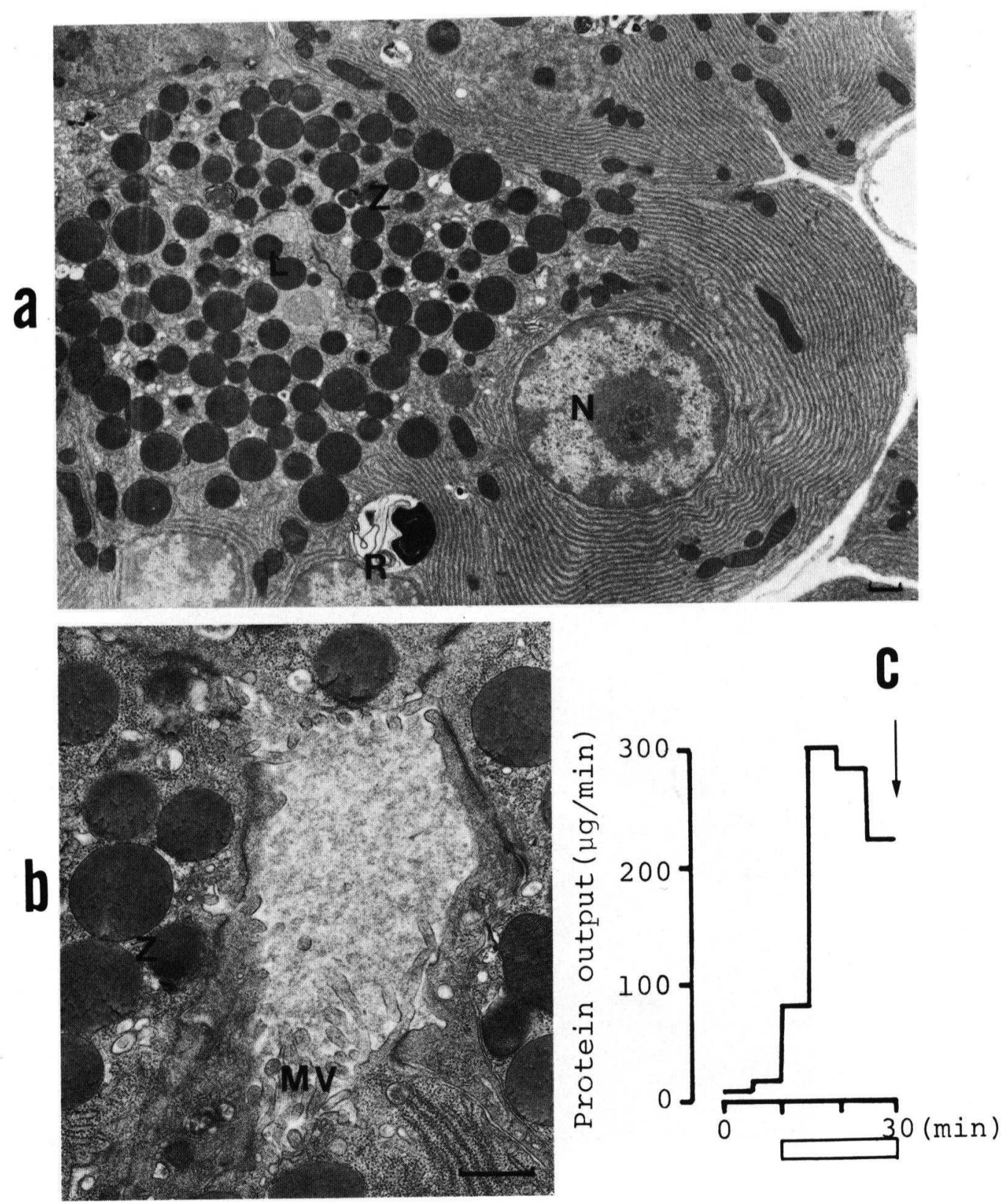

Fig. 6 Electron micrographs after continuous stimulation with $1 \mathrm{nM} \mathrm{CCK}-8$ combined with $100 \mathrm{pM}$ secretin. a: The acinar cell ultrastructure is normal. Note the round and uniform zymogen granules $(Z)$ and the absence of 'lakes' of zymogen material from the cytoplasm. L, acinar lumen; R, residual body; N, nucleus. The horizontal bar represents $1 \mu \mathrm{m}$ calibration. b: The acinar lumen is somewhat dilated and contains fine granular secretory material. Note the uniform, round zymogen granules (Z) and normal microvilli (MV). Calibration as in a. c: Time course of protein output of the preparation examined by electron microscopy before and after continuous stimulation with $1 \mathrm{nM}$ CCK- $8+100 \mathrm{pM}$ secretin. Other symbols as in Fig. 2 


\section{Microfilaments Containing Immunoreactive Actin}

In normal pancreas and pancreas stimulated with $100 \mathrm{pM}$ CCK-8, the anti-actin antibody reaction product was found preferentially on the narrow and smooth luminal border of acinar cells (Fig. 7a). The anti-actin antibody also reacted rather weakly with the basal cell margin of the acinus (Fig. 7b).

In the pancreas stimulated either with $1 \mathrm{nM}$ or $100 \mathrm{nM}$ CCK-8, the reaction product for actin disappeared from the strikingly dilated luminal surface of acinar cells (Fig. 7c), while the boundary to the basal border of the acinus was left unchanged.

When the pancreas was stimulated with $100 \mathrm{nM}$ CCK-8 in combination with $100 \mathrm{pM}$ secretin, the disappearance of actin was prevented, and the reaction product for actin was shown at the narrow and straight luminal border of acinar cells (Fig. 7d). A low concentration of VIP $(100 \mathrm{pM})$ also prevented the disappearance of actin from the luminal border of the acinar cells.

\section{DISCUSSION}

\section{Secretin Prevents Hyporeactive Secretory} Responses to Supraoptimal CCK-8 Stimulation

$\mathrm{CCK}$ and ACh are the physiological stimuli to which the pancreatic acinar cells respond by releasing the contents of zymogen granules into the acinar lumen. These physiological stimuli have both an optimal concentration that produces the maximal secretory responses. At concentrations higher than the optimal concentration, the secretory responses are smaller and decline rapidly (hyporeactive response). These biphasic responses to increasing concentrations of secretagogues result in a bell-shaped doseresponse relation. This pattern of pancreatic secretory responses has been demonstrated in vivo with $\operatorname{CCK}(6,9,20)$ and $\mathrm{ACh}(13)$; in pancreatic fragments and isolated acini with $\mathrm{ACh}(6$, 11), carbamylcholine $(13,29,31,32)$, pilocarpine (25), $\operatorname{CCK}(31,32)$, and caerulein $(32,33)$; and in isolated perfused pancreas with CCK (14) and with ACh (11). Further increase in concentrations of the secretagogues caused a leak of secretory products into the portal vein (30). The hyporeactive secretory responses were confirmed in the present study: the secretory responses to $1 \mathrm{nM}$ CCK-8 were transient and significantly smaller than those to $100 \mathrm{pM}$ CCK- 8 which produced maximal responses. Furthermore, we now present evidence that $100 \mathrm{pM}$ secretin prevents the hyporeactive responses to $1 \mathrm{nM}$ CCK-8.

\section{Morphological Alterations Coincide with Hyporeactive Response}

A previous study showed that the secretin caused small but distinct amylase release which was abolished in a calcium-deficient environment (18) in the isolated perfused rat pancreas. This and the present results support the view that secretin and CCK receptors coexist on the basolateral surface of the acinar cell (10). However, the previous and the present morphological studies suggest that the hyporeactive response to supraoptimal CCK-8 and the preventive effect of secretin on the hyporeactive response may not be at the receptor level but in the post-receptor intracellular processes of stimulus-secretion coupling. Savion and Selinger (31) showed in pancreatic slices incubated in vitro that the hyporeactive response was associated with morphological changes in the luminal plasma membrane of acinar cells. Recently, the hyporeactive response to high concentration of secretagogues has attracted special interest in connection with early morphological changes during the development of experimental pancreatitis (34). Rats infused with a supraoptimal dose of the CCK analog caerulein develop acute interstitial pancreatitis (19). Watanabe et al. (34) have studied the early morphological changes in pancreatic acinar cells induced by infusing supramaximal caerulein in the conscious rat, and showed that, shortly after the onset of caerulein infusion, large vacuoles appeared in the Golgi area, and, after longer periods of infusion, these vacuoles further enlarged and became more widely distributed in the cytoplasm. These large vacuoles were found to be acid phosphatase positive and to be labeled by antibodies directed against digestive zymogens as well as the lysosomal enzyme cathepsin D. In the present study, we also found such large vacuoles (cytoplasmic 'lakes') in the acinar cells stimulated with supramaximal CCK8 concentrations for $20 \mathrm{~min}$ in the isolated perfused rat pancreas.

\section{Involvement of Contractile Proteins in Morphological Alterations Coincided with Hyporeactive Responses}

The importance of calcium and contractile proteins has been recognized in the hyporeactive and morphological alteration induced by supraoptimal stimulation with various secretagogues. 

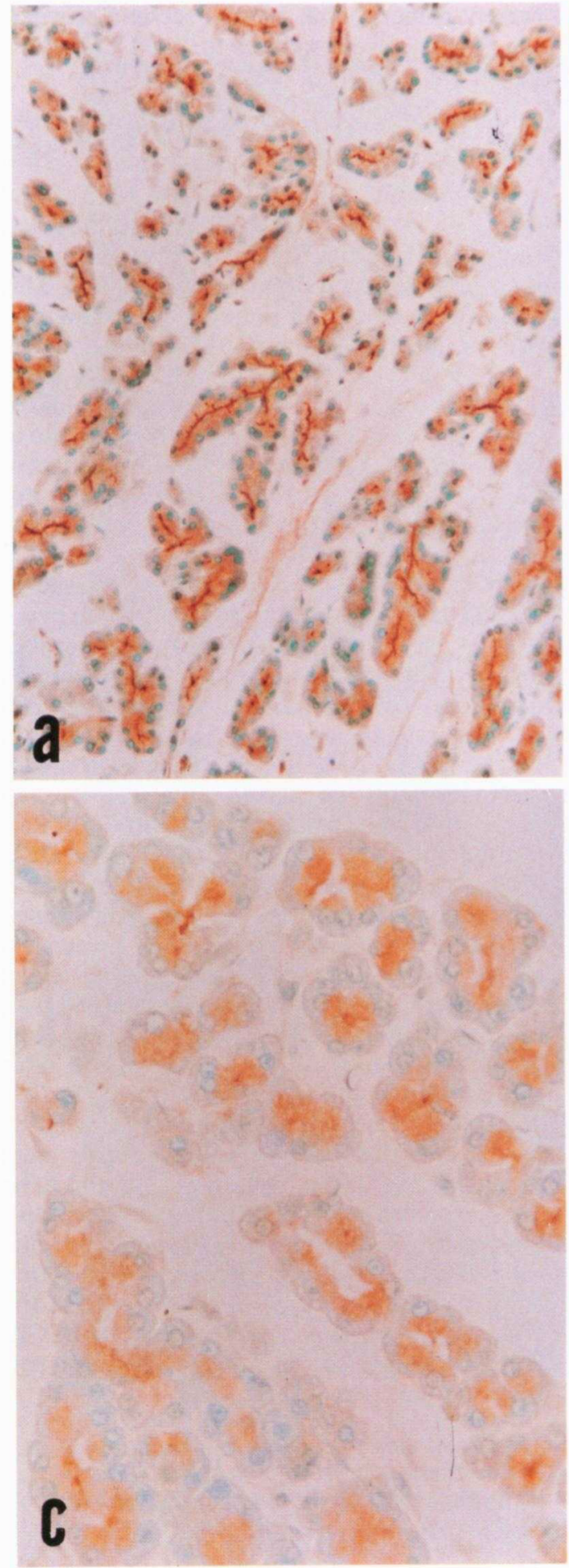

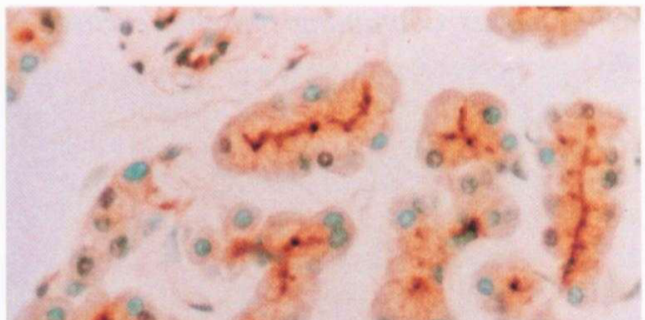
$\therefore 4: 50$

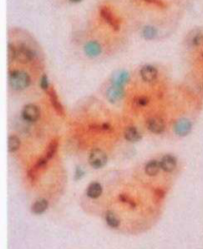
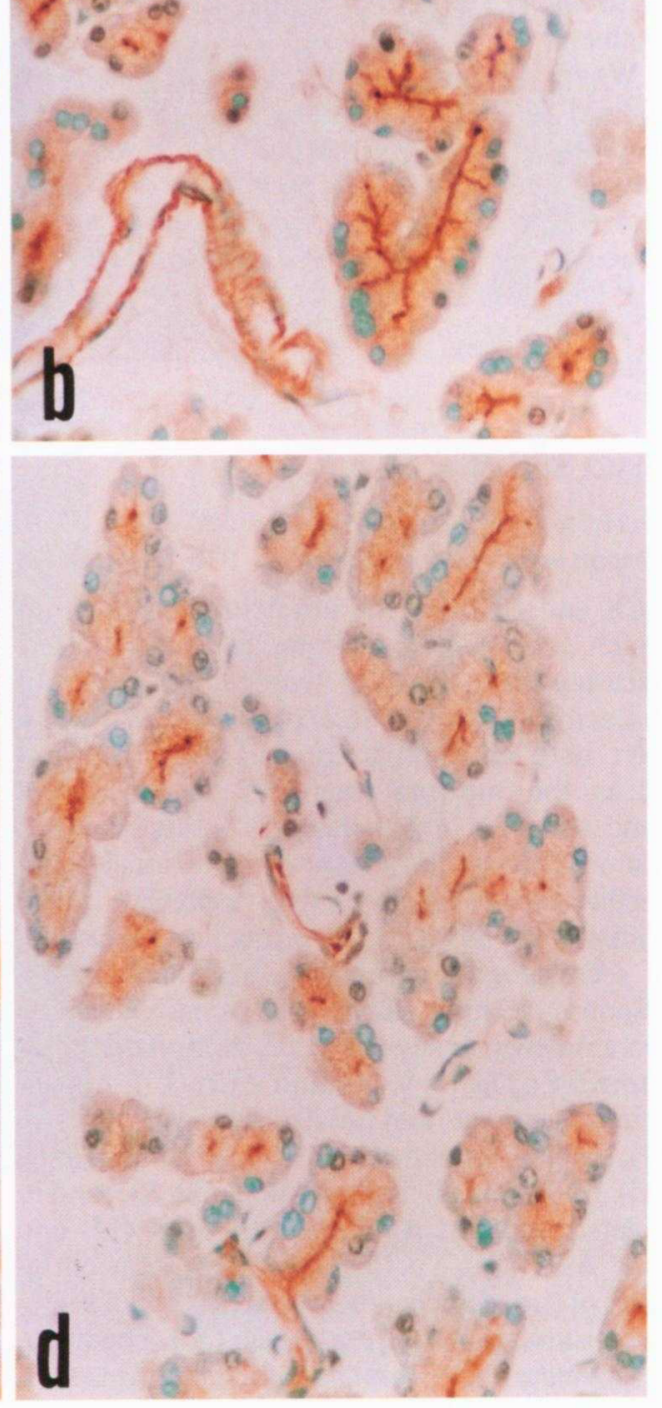

Fig. 7 
The disappearance of microvilli and disruption of the filamentous structures occurred after $15 \mathrm{~min}$ of incubation in the presence of $1 \mathrm{mM}$ carbamylcholine (31). Furthermore cytochalacin $\mathrm{B}$ caused the disappearance of apical microfilaments and, most strikingly, completely converted the morphological change induced by 10 nM CCK-8 (3). In this respect, it is of interest that actin (2) and myosin (7) have been detected in the rat pancreas by immunocytochemical methods. The present study demonstrated that, in the isolated perfused rat pancreas: 1) the microfilament structure containing immunoreactive actin was depolymerized by supraoptimal stimulation with $1 \mathrm{nM} \mathrm{CCK-8;} \mathrm{and} \mathrm{2)} \mathrm{struc-}$ ture was preserved when the pancreas was stimulated simultaneously with $100 \mathrm{pM}$ secretin and $1 \mathrm{nM}$ CCK-8.

\section{Cellular Mechanism of Preventive Effect of Secretin on Hyporeactive Responses}

The principal finding in the present study is that secretin prevents the early morphological changes and hyporeactive secretory responses induced by stimulation with supramaximal CCK-8, whereas secretin potentiates the CCK-8induced secretory responses. The finding provides an experimental basis for the recent study (28) that intravenous secretin given simultaneously with ceruletide, the diethylamine salt of cerulein, exerted a striking macroscopic, microscopic, and biochemical protective effect on ceruletide-induced pancreatitis in anesthetized rats. The fact that secretin prevents the degenerative changes in the hyperstimulated acinar cells indicates that supramaximal doses of CCK per se are not toxic to acinar cells in a non-specific manner but rather act through exaggerated physiological mechanisms. The present finding is compatible with the view that the effect of secretin to prevent hyporeactive responses lies

Fig. 7 Micrographs demonstrating immunoreactive actin. a: Pancreatic acinar cells without CCK-8. The anti-actin antibody bound to the luminal border of acinar cells. $\times 200$. b: Acinar cells after continuous $20 \mathrm{~min}$ stimulation with 100 pM CCK-8. The anti-actin antibody has reacted also with the basal margin of the acinus. $\times 400$. c: Acinar cells after continuous stimulation with $100 \mathrm{nM}$ CCK-8. The reaction product for actin has disappeared from the luminal surface of acinar cells. Note the dilated acinar lumen. $\times 400$. d: Acinar cells after continuous stimulation with $100 \mathrm{nM} \mathrm{CCK}-8$ in combination with $100 \mathrm{pM}$ secretin for $20 \mathrm{~min}$. The reaction product for actin is visible at the narrow and straight luminal border of acinar cells. $\times 400$ in the post-receptor intracellular processes of stimulus-secretion coupling, and sheds light on the cellular mechanism of hyporeactive responses to high concentration of secretagogues in acinar cells.

The view that the hyporeactive response is due to post-receptor intracellular processes has also been supported by the functional studies, which demonstrated that the hyporeactive response was not overcome by a different calcium-mediated secretagogue or by bypassing the receptor with the calcium ionophore A23187 (1, 31, 37). $\mathrm{CCK}$ and $\mathrm{ACh}$ act on their respective receptors to increase their major intracellular second messenger, $\left[\mathrm{Ca}^{2+}\right]_{\mathrm{i}}$, which, in turn, increases the frequency of exocytosis of zymogen granules (4, 36). The extreme increase in $\left[\mathrm{Ca}^{2+}\right]_{\mathrm{i}}$ (more than $1 \mu \mathrm{M})$ resulted in distinct inhibition of secretagogue-induced amylase output (26). Savion and Selinger (31) have proposed that the common parameter mediating the induction of both the hyporeactive enzyme secretion and the activation of the lysosomal system is the increase in $\left[\mathrm{Ca}^{2+}\right]_{i}$, and the supraoptimal concentration of secretagogues increases the $\left[\mathrm{Ca}^{2+}\right]_{i}$, which in turn causes disaggregation and disruption of the filamentous system.

On the other hand, cAMP is regarded as the major intracellular second messenger of secretin- and VIP-induced protein secretion in the pancreatic acinar cell (10). Thus, a synergistic and equilibrating interaction between cAMP and calcium ion in the pancreatic acinar cell may be involved in the post-receptor mechanism responsible for secretin preventing the hyporeactive response and morphological changes, which occur with supraoptimal concentrations of CCK8. A possible site of the interaction between cAMP and calcium ion may be calmodulin in the acinar cell (12) since calmodulin is known to be an activator of cyclic nucleotide phosphodiesterase and to be activated by calcium ion (23).

Another post-receptor mechanism for the preventive effect of secretin may be in the transcellular transport of $\mathrm{NaCl}$ and $\mathrm{CaCl}_{2}$, both of which may play cardinal roles in stimulus-secretion coupling $(14,15)$. A study in recent year by Renckens et al. (27) suggests that the processes between the intracellular calcium release and exocytosis could be blocked by the reduction in $\mathrm{Na}^{+}$concentration across the plasma membrane. This mechanism should be elucidated by further investigation.

The investigation was supported by Grant-in-Aid of Scientific Research (No. 57440022 and 56370004) to 
T.K. from the Ministry of Education, Science and Culture, Japan, and the Miura Medical Research Foundation to T.K.; and grants from the Sapporo Medical College, the Paulo Foundation, and the Sigrid Juselius Foundation to T. J. N.

\section{Received for publication 24 June 1984}

\section{REFERENCES}

1. Abdelmoumene S. and Gardner J. D. (1980) Cholecystokinin-induced desensitization of enzyme secretion in dispersed acini from guinea pig pancreas. Amer. J. Physiol. 239, G272-G279

2. Bendayan M., Marceau N., Beaudoin A. R. and Trifaro J. M. (1982) Immunocytochemical localization of actin in the pancreatic exocrine cell. $J$. Histochem. Cytochem. 30, 1075-1078

3. Burnham D. B. and Williams J. A. (1982) Effects of high concentrations of secretagogues on the morphology and secretory activity of the pancreas: A role for microfilaments. Cell Tissue Res. 222, 201-212

4. CASE R. M. (1978) Synthesis, intracellular transport and discharge of exportable proteins in the pancreatic acinar cell and other cells. Biol. Rev. 53, 211-354

5. Chang T.-M. and Chey W. Y. (1983) Radioimmunoassay of cholecystokinin. Digest. Dis. Sci. New Series 28, 456-468

6. Debray C., Vaille C., De La Tour J., Roze C. et SouchaRd M. (1963) La pancreozymin. Etat actuel de la question. Son action sur la secretion biliare et pancreatique externe du rat. Rev. Int. Hepatol. 13, 473-499

7. Drenckhahn D., Gröschel-Stewart U. and UNSICKER K. (1977) Immunofluorescence-microscopic demonstration of myosin and actin in salivary glands and exocrine pancreas of the rat. Cell Tissue Res. 183, 273-279

8. FAHRENKRUG J. (1980) Role of VIPergic neurons in pancreatic bicarbonate secretion. Biomedical Res. 1, Suppl., 84-87

9. Fölsch U. R. and Wormsley K. G. (1973) Pancreatic enzyme response to secretin and cholecystokinin-pancreozymin in the rat. J. Physiol. 234, 79-94

10. Gardner J. D. and Jensen R. T. (1980) Receptor for secretagogues on pancreatic acinar cells. Amer. J. Physiol. 238, G63-G66

11. Habara Y. (1980) Influences of ionic environments on ACh-induced secretory responses in isolated perfused pancreas of rats. Jap. J. Physiol. 30, 561-574

12. Heisler S., Chauvelot L., Desjardins D., Noel C., LAMBert H. and DesY-Audet L. (1981) Stimulus-secretion coupling in exocrine pancreas: possible role of calmodulin. Can. J. Physiol. Pharmacol. 59, 994-1001

13. Hokin M. R. (1968) Studies on chemical mechanisms of the action of neurotransmitters and hormones. II. Increased incorporation of ${ }^{32} \mathrm{P}$ into phosphatides as a second, adaptive response to pancreozymin or acetylcholine in pigeon pancreas slices. Arch. Biochem. Biophys. 124, 280-284

14. Kanno T. (1975) The electrogenic sodium pump in the hyperpolarizing and secretory effects of pancreozymin in the pancreatic acinar cell. J. Physiol. 245, 599-616

15. Kanno T., Saito A. and Sato Y. (1977) Stimulussecretion coupling in pancreatic acinar cells: influences of external sodium and calcium on responses to cholecystokinin-pancreozymin and ionophore A23187. J. Physiol. 270, 9-28

16. Kanno T., ShibuYa I. and Asada N. (1983) The role of extracellular calcium and other ions in the secretory responses of the exocrine pancreas to cholecystokinin. Biomedical Res. 4, 295-302

17. Kanno T., Suga T. and Yamamoto M. (1976) Effects of oxygen supply on electrical and secretory responses of humorally stimulated acinar cells in isolated rat pancreas. Jap. J. Physiol. 26, 101-115

18. Kanno T. and Yamamoto M. (1977) Differentiation between the calcium-dependent effects of cholecystokinin-pancreozymin and the bicarbonate-dependent effects of secretin in exocrine secretion of the rat pancreas. J. Physiol. 264, 787799

19. Lampel M. and Kern H. F. (1977) Acute interstitial pancreatitis in the rat induced by excessive doses of a pancreatic secretagogue. Virchows Arch A Pathol. Anat. Histol. 373, 97-117

20. Leroy J., Morisset J. A. and Webster P. D. (1971) Dose-related response of pancreatic synthesis and secretion to cholecystokinin-pancreozymin. $J$. Lab. Clin. Med. 78, 149-157

21. Lowry O. H., Rosebrough N. J., Farr A. L. and Randall R. J. (1951) Protein measurement with the Folin phenol reagent. J. Biol. Chem. 193, 265275

22. Luft J. H. (1971) Ruthenium red and violet. I. Chemistry, purification, methods of use for electron microscopy and mechanism of action. Anat. Rec. 171, 347-368

23. Means A. R., Tash J. S. and Chafouleas J. G. (1982) Physiological implications of the presence, distribution, and regulation of calmodulin in eukaryotic cells. Amer. Physiol. Soc. 62, 1-38

24. Nevalainen T. J. (1970) Effects of pilocarpine stimulation on rat pancreatic acinar cells. Acta Pathol. Microbiol. Scand. A 210, Suppl. 1, 1-43

25. Nevalainen T. J. and Janigan D. T. (1974) Pilocarpine stimulation of exocrine pancreas secretion in vitro. Res. Exp. Med. 162, 161-167

26. O'DOHERTY J. and Stark R. J. (1982) Stimulation of pancreatic acinar secretion: increases in cytosolic calcium and sodium. Amer. J. Physiol. 242, G513G521

27. Renckens B. A. M., Van Nooy I. G. P., De Pont J. J. H. H. M. and Bonting S. L. (1981) Role of calcium in exocrine pancreas secretion. VII. Effect of sodium on enzyme secretion and calcium metabolism in rabbit pancreatic fragments and acinar cells. Biochim. Biophys. Acta 643, 519-534 
28. Renner I. G. and Wisner J. R. (1983) Protective effects of exogenous secretin on ceruletideinduced acute pancreatitis in the rat. J. Clin. Invest. 72, 1081-1092

29. Robberecht P. and Christophe J. (1971) Secretion of hydrolases by perfused fragments of rat pancreas: effect of calcium. Amer. J. Physiol. 220, 911-917

30. Saito A. and Kanno T. (1973) Concentration of pancreozymin as a determinant of the exocrineendocrine partition of pancreatic enzymes. Jap. J. Physiol. 23, 477-495

31. Savion N. and Selinger Z. (1981) Inhibition of enzyme secretion and autophagy of secretory granules caused by action of high concentration of secretory hormones on rat pancreatic slices. In Meth. Cell Biol. 23 (ed. Hand A. R. and Oliver C.) Academic Press, New York, pp. 359-378

32. Scheele G. A. and Palade G. E. (1975) Studies on the guinea pig pancreas. Parallel discharge of exocrine enzyme activities. J. Biol. Chem. 250, $2660-2670$
33. Vincent D. et Bauduin H. (1972) Influence de la ceruleine sur la secretion et le metabolisme du pancreas exocrine du rat in vitro. Biol. Gastroenterol. 5, 85-90

34. Watanabe O., Baccino F. M., Steer M. L. and Meldolesi J. (1984) Supramaximal caerulein stimulation and ultrastructure of rat pancreatic acinar cell: early morphological changes during development of experimental pancreatitis. Amer. J. Physiol. 246, G457-G467

35. Williams J. A. (1975) An in vitro evaluation of possible cholinergic and adrenergic receptors affecting pancreatic amylase secretion. Proc. Soc. Exp. Biol. Med. 150, 513-516

36. Williams J. A. (1980) Regulation of pancreatic acinar cell function by intracellular calcium. Amer. J. Physiol. 238, G269-G279

37. Williams J. A., Korc M. and Dormer R. L. (1978) Action of secretagogues on a new preparation of functionally intact, isolated pancreatic acini. Amer. J. Physiol. 235, E517-E524 